\title{
Framing Mobility. \\ Refugees AND the Social Imagination
}

\section{Heidrun FRIESE, Institute for German and Communication Studies, Technische Universität Chemnitz}

\section{Content}

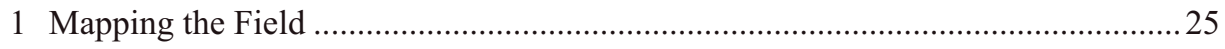

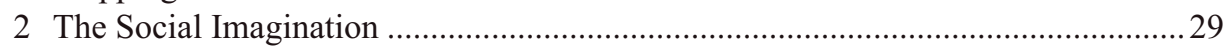

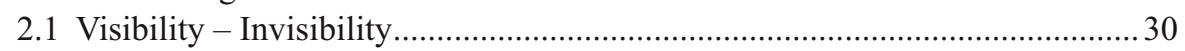

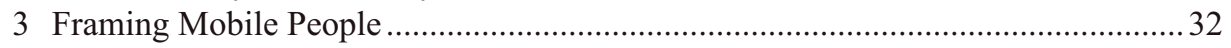

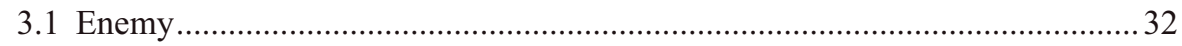

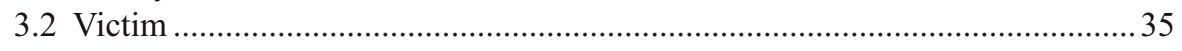

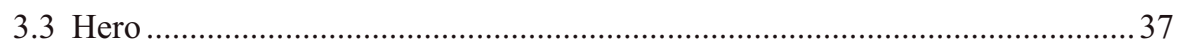

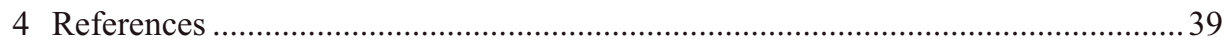

\section{Mapping the Field}

Following the deaths of more than three hundred people close to the shores of the southern Italian island of Lampedusa on October 3, 2013, increased media hype and global attention have sought to address mobility in the Mediterranean, and the highly controversial negotiation of hospitality therein. ${ }^{1}$ As a result, since then, the name 'Lampedusa' has become an empty signifier. ${ }^{2}$

This article was initially published in: Migration. Changing concepts, Critical Approaches. Edited by Doris Bachmann-Medick and Jens Kugele. 2018 Berlin/Boston, Walter de Gruyter. 2 A discussion of the notions of 'empty signifier' or 'floating signifier' and its various theoretical implications, reaching from Claude Lévi-Strauss to Roland Barthes, Jean Baudrillard, Ernesto Laclau, and Jacques Derrida, is not intended. Furthermore, the differences between master signifier and hegemonic signifier in Slavoj Žižek and Ernesto Laclau cannot be discussed here. The following remarks instead take up an argument developed in FrIESE 2017, FrIESE 2017a, and FRIESE 2017b. 
Media images of overcrowded and flimsy vessels, shipwrecks and death, and catastrophe and tragic loss fuel the notion of a tragic border regime. At the same time, racialized images of 'black masses' evoke an 'invasion,' an uncontrollable 'flood.' Dramatic pictures of debilitated people arriving on the island reinforce a social imagination that views so-called 'undocumented mobility' as a humanitarian catastrophe, or as a threat to Europe's welfare and national identities that asks for drastic and robust measures against 'traffickers' as well as for a permanent "state of exception," that became a normal paradigm of government as the camp became a nomos of modernity ${ }^{3}$ (AGAMBEN 2003). Critical stances, humanitarian impetuses of rescue, and fantasies of invasion intersect in media representations of this situation. In June 2011, Angelina Jolie-Pitt, American actress and Goodwill Ambassador of the UN High Commissioner for Refugees, arrived on Lampedusa; stating that she "was moved" by the boatpeople. Soon thereafter, the former head of the French Front National Marine Le Pen, the former Prime Minister of Italy Silvio Berlusconi, and Pope Francis personalized competing socio-political discourses by emphasizing either humanitarian or security-oriented aspects of mobility, demarcating common conceptions of the "limits of hospitality" (FRIESE 2014). Then, following the shipwreck in October 2013, global media and national politicians gathered around coffins of the victims to join in the humanitarian spectacle. And a few weeks later, the mission Mare Nostrum was launched, which not only pursued humanitarian Search and Rescue (SAR) missions, but also served in policing the Channel of Sicily next to the Libyan coast. ${ }^{4}$

As an empty signifier, 'Lampedusa' became mobile, and reached Europe's capital cities. On Berlin's Oranienplatz, a media-saturated Lampedusa Village accommodated local activists from the Kreuzberg neighborhood, who declared: Lampedusa is everywhere. This transfer between tropics allowed the historical and geographical site of Lampedusa to now be 'located' literally any- and everywhere, interchanging center and periphery, and proving the power of what the signifier could activate and mobilize. It allowed for different political positions - populist, humanitarian, and critical - as well as a perspective that imagines the foreigner as a hero, a substitute for a lost revolutionary subject. Alongside inherited images of the foreigner as enemy or victim, the old image of the foreigner as liberator could thus be activated.

The global mediatization of mobility and its critical-antagonistic discourses about security, humanitarianism, and activism led to an astonishing media prominence for the island and its six thousand inhabitants. In interviews, locals commented rather skeptically on the onslaught of aid-workers, activists, and scientists, with statements that consistently echoed the following sentiment: "They arrive and depart but nobody keeps an interest in local problems." Additionally, locals voiced fears that global

\footnotetext{
On the relations between mobility, 'aesthetics, ethics, and politics' see MusArò and PARMIGGIANI 2014.

${ }_{4} \quad$ Mare Nostrum has been replaced by the Frontex lead mission Triton and EU NAVFOR MED Operation Sophia, launched in June 2015, with the aim of countering the activities of human smugglers and traffickers in the Mediterranean.
} 
media coverage might damage the image of the island as an uncontaminated paradise for leisure and tourists, its powerful production of images consuming Lampedusa as a historical place. Previously known only to a limited number of tourists, Lampedusa has to deal with global media attention, scientific discourse, and artists' representations, becoming part of the global social imagination and its signifying processes. For example: Maria Iorio's and Raphaël Cuomo's film Sudeuropa (2005-07) explores visibility and invisibility with reference to tourism and the camp on Lampedusa; and Zakaria Mohammed Ali's film To Whom it May Concern (2008), Jakob Brossmann's images Lampedusa im Winter (2015), and Gianfranco Rosi's Fuocammare (2016) depict varying perspectives on the island as well. Morgan Knibbe's Shipwreck (2014) offers a narration of the shipwreck of October 3, 2013; Enrico Chiarugi recites the names of the perished; and Havarie (2016), by Philip Scheffner, points its camera on a flimsy refugee boat. Giuseppe Di Bernardo, in Viaggio a Lampedusa (2010); Costanza Quatriglio, in LampeduSani (2014); and Davide Camarrone, in Lampaduza (2014) document their trips to the island. Migrants' belongings and parts of boats arriving on Lampedusa are used in artwork and shown in museums; the composer Ennio Morricone sets the voices of the drowned to music. Lampedusa is presented on stage by Henning Mankell, in Lampedusa (2006); by the Théâtre Senza, in Miraculi (2014); and by the Italo-Tunisian theater Teatro dell'Argine/Eclosion D'Artistes, in Lampedusa Mirrors (2015). Lina Prosa offers a trilogy of shipwrecks (2013), and the writer Maylis de Keregal reflects on the Mediterranean tragedy (2015). By no means exhaustive, this list indicates the glut of artistic production and reproduction of emotion designed to move the spectator, and to inscribe the migrant's destiny onto a powerful narration of misery, pity, indignation, and victimhood.

The making of borders and the governmentality of mobility comprises an ensemble of multiple and even contradictory actors, practices, models, and economic calculation (Foucault 2006). These historically shifting constellations -no longer ordered by a centralized site of power - are shaped by (military) technologies of policing and surveillance, administrative acts and logics, pastoral practices and orientations, humanitarian impetuses and scientific discourse. On one hand, the dominant discourse of security brings forth scenarios of threat. It insists on the defense of national sovereignty or, in its culturist version, on an alleged national identity, opting for the increasing surveillance of borders if not the outright shielding of national territories against an 'invasion.' On the other hand, humanitarian and critical discourses address (religious) prescriptions, ethics, and values; or (antagonistic) political mobilization. The social imagination and images of mobile people are part of governmentality, its techniques, and its production of truth and power. Images are certainly not innocent, nor are processes of signification. Mixing tragic fate with guilt and pathos, anguish and suffering, the social imagination and the production of specific images and figures of mobile people as enemies, victims, or heroes are part of such powerful constellations.

If we follow Cornelius CASTORIADIS' understanding of tragedy as political drama displaying conflicts that make up the political (1997, p. 284), then the border regime 
is to be considered tragic: not because human beings are left to die at the borders, ${ }^{5}$ but because the border regime reveals and elaborates the founding tensions of democracy. ${ }^{6}$ The central feature of democracy is autonomy: the autonomy of a demos, the polis, to determine its own laws. Democracy is founded on its own autonomous will, and it is the explicit political form of an autonomous political community. As no (divine) law is "above" the demos as autonomous subject of legislation, it grounds itself in autonomous will. Such circularity - a demos decides who is to be the demos - opens up the paradox of the original and arbitrary moment of foundation, which decides about membership, citizenship, and borders. At the same moment, it is therefore inclusive and exclusive. (Undocumented) mobility challenges democracy as it points towards the democratic paradox of the constitution of the demos, a political community that is founded on the exclusion of those who do not belong. Discourse on mobility cannot escape the basic paradox of democracy, which always already sets the limits of hospitality and marks the figure of the stranger.

Media hype, the pathos of the event-society, and the "economy of attention" (CitTon 2014) make the tragic border regime work. Much as the routes of migrants from Turkey to the Aegean islands of Kos and Lesbos have attracted massive media coverage (in early September 2015 the picture of Alan al-Kurdi's body, washed ashore on the holiday beach of Kos, became a media icon and "a symbol of refugee misery"), ${ }^{7}$ Lampedusa is likewise a prominent part of the popular media spectacle, an eternal backdrop of 'tragic' and 'catastrophic' events. The island became the terra santa of pilgrimage, the veneration of innocent victims, and the repository of 'authentic' feelings of post-humanitarian catharsis. Images of indignation and pity are constantly produced, staged, and replayed. ${ }^{8}$

5 Following the United Nations High Commissioner for Refugees report, in 2015 at least 3,770 people died or were reported as missing in the Mediterranean. (UNCHR 2015, p. 32) In 2016, 5,079 people drowned. The death toll of these voyages therefore amounted to 14 dead people per day. (<https://missingmigrants.iom.int/mediterranean> [accessed: 01 March 2017]). In 2015, 1,015,078 refugees crossed the Mediterranean; and around 850,000 crossed the Agean Sea. According to the Italian Minister of the Interior, 181,436 people reached Italy in 2016. <www. libertaciviliimmigrazione.dlci.interno.gov.it/sites/default/files/allegati/cruscotto_statistico_ giornaliero_31_dicembre.pdf $>$ [accessed: 01 December 2017].

Furthermore, it reveals "self-limitation," and, "more than that, tragedy shows not only that we are not masters of the consequences of our actions but that we are not even masters of their meaning." (CASTORIADIS 1997, p. 284)

"Refugee crisis: Following the tragic journey of Alan Kurdi's family from Syria to Kos. The death of Alan al-Kurdi en route to the holiday island has made it a symbol of refugee misery." Saturday, September 5, 2015 23:13 BST, The Independent. <http://www.independent.co.uk/news/ world/europe/refugee-crisis-following-the-tragic-journey-of-aylan-kurdis-family-from-syria-tokos-10488358.html $>$ [accessed: 10 November 2015]. Regarding contemporary art, I am referring to the pictures taken of Ai Weiwei at the shores of Lesbos, their display of tragic misery, and their intent to transmit authenticity while resting within the simulacrum of repetition. <http:// www.repstatic.it/content/nazionale/img/2016/01/31/215336129-fb4b9d87-1c56-46ca-be4f64e82f2b2929.jpg > [accessed: 17 April 2017]

In contrast, the social imagination and the images produced by the North-African harragas (as people who "burn the borders" are called throughout the Maghreb) challenge the dominant 
The following section addresses the social imagination and the organization of visibility and invisibility in public discourse. Against this background, the staging of mobile people as enemy, victim or hero will be analyzed, in an effort to show how the social imagination is connected to the border regime, the migration industry, and current governance, which will be shown to legitimize a continuum of political positions, taking populist, humanitarian or critical perspectives.

\section{The Social Imagination}

"Each society," Cornelius Castoriadis points out, "is a construction, a constitution, a creation of a world, of its own world" (CASTORIADIS 1987, 3). Social imagination however, cannot be considered as a "mere copy, a reflection of the outside world." Rather, the imagination allows for human relations, intersubjectivity and the "social-historical world" (ELLIOT 2012, p. 355). The social imagination thus, does not merely call forth visible images, symbols, and iconographies, but is "a fundamental creation of the social imaginary, [wherein] the gods or rules of behavior are neither visible nor even audible but signifiable" (CASTORIADIS 1997, pp. 182-183, emphasis mine). Social imagination relates "an aesthetics of imagination [and] the primary institutions of society (language, norms, customs and law)." As such, it is to be understood as a "form of relation through which individuals and collectivities come to relate to such objects of representational and affective investment" (Elliot 2012, p. 356). The social imagination therefore, not only creates and allows for intersubjectivity, but society is moved by "the work of creative imagination, the eruption of a radically new that did not exist in any prior form" (ELLIOT 2012 , p. 355). Therefore, the social imagination is not a mere reproduction of society, a secondary or 'second order' product, but one that plays a decisive and vital role in the creation, reshaping, and reorganization of social life.

In this sense, a space of negotiation is enabled by the production of images of the 'stranger' as one who does not belong to a political community, who is not endowed with the same rights as a European citizen, and whose exclusion from the political community nonetheless creates the political community. As part of the social imagination's processes of signification, these images constitute society, and are endowed with the creative power to constantly reshape the social and political order. The social imagination thus constitutes and shapes the space of the political, and it organizes presence and absence, visibility and invisibility.

imaginaries of 'undocumented' mobility (for such an account, see FrIESE 2013, 2017b). The harraga experience of people from the Maghreb, however, is very different from experiences that sub-Saharan people encounter on their journeys, as they often have to face racism, brutal exploitation, and imprisonment in Libya. 


\subsection{Visibility - Invisibility}

The social imagination and its processes of signification create those who are excluded, pointing toward global asymmetries and the repressed traces of colonialism, and carrying a postcolonial framing. Media attention and strategies of visualization certainly do not escape this ordering, but instead bring forth an astonishing movement between visibility and invisibility. Despite massive media coverage, those who arrive on Lampedusa are invisible, as they are usually immediately transferred to a reception center situated at the periphery of the island's small village (Centro di primo soccorso $e$ accoglienza, Cpsa, a so-called 'hot spot' for identification and registration). The migrants are then not permitted to leave the center, nor is the public permitted to visit the camp.

In such a way, the status of these clandestini, and the semantic vicinity of the stranger to this secret and potential threat, is repeated and enforced. Clandestini, the Italian term for illegalized mobile people, points towards 'that which is kept secret or is done secretly' because it is prohibited. Etymologically, the word's root, clan, signifies 'hidden' (di nascosto), from kal/cal as that which is hidden from the light of the day (dies); that which is 'hidden from light or sheds the light of the day.' The "secret," as Jacques Derrida notes (DerRIDa 2002, p. 198), is the "separated," which marks as well the double presence of the clandestini: present and absent, invisible and visible.

Images mobilize, and visibility is part of political strategy. Therefore, the clandestini, the invisibles, must become visible if they are to be marked as enemy, as a threat that legitimizes the practices of the border regime, its governance, and its eminent economic interests. The media's gaze, the production of visibility, the staging of the invasion of 'black masses,' and the conjured 'exodus of biblical dimensions' serve the production of illegality and become part of the tragic border regime. In the same vein, visibility is a vital feature of humanitarian and critical discourse. Suffering has to be made visible in order to move the spectator and to raise indignation and eventually action. In order to understand the common features connecting humanitarian to critical discourse, we must take a short historical detour: "History tells us that it is by no means a matter of course for the spectacle of misery to move men to pity," Hannah ARENDT remarks $(1963$, p. 70$)$. The poor person's misery is due to the fact that while "he is not disapproved, censured, or reproached; he is only not seen [...]. To be wholly overlooked, and to know it, [is] intolerable" (ARENDT 1963, p. 69, emphasis mine). Revolutionary pathos and

the personal legitimacy of those who represented the people and were convinced that all legitimate power must derive from them, could reside only in $[. .$.$] the capacity to suffer with the "immense class of the poor,"$ accompanied by the will to raise compassion to the rank of the supreme political passion and of the highest political virtue. (ARENDT 1963, p. 75, emphasis mine) 
The visibility of the poor in the course of the French Revolution was related to a public compassion with the malheureux (ARENDT 1963, p. 94). Visibility, thus, is bound on one hand to compassion, and to the (political) structures of "recognition," the becoming visible in the public sphere, on the other (HoNNETH 2003).

Luc Boltanski's Distant Suffering (1999) takes up Hannah Arendt's analysis in examining at modes and practices of compassion that are not directed towards the immediate environment or the concrete and immediate sight of suffering, but rather to distant concerns and mediated suffering. BOLTANSKI's account concerns ethics and moral philosophy as well as the question of how indignation and political action in the face of human suffering are developed. In order to address these questions, he develops a triple topic: the "topic of denunciation," the "topic of sentiment" and the "aesthetic topic" (BOLTANSKI 1999). One may add to this the topic of knowledge, as social science may contribute to political mobilization (even if individual suffering is not at the center of its attention). These topics display tensions between the universal and the particular, between mass and singular suffering:

In fact, while it is easier to integrate general forms of presentation into the logic of political programs [...], nonetheless it is necessary to go into particular cases, that is go into details, in order to arouse pity, involve the spectator and call on him to act without delay. (BOLTANSKi 1999, p. 33)

Such a dispositif, however, has been modified, not least with the day-to-day use of digital media. Pity, commotion, and solidarity were once tied to religious prescription; moral-philosophic universalism; or 'grands récits' that distanced suffering through insight, critical judgement, and knowledge. Today, however, suffering is imprinted into the subjectivity of the spectator. Universality has been replaced by irony, and subjectivity and reason have been replaced by authenticity. Solid principles have been converted into consumerism, and rational judgment into subjective opinion. Solidarity has transformed into a feature of the lifestyle industry and the "ironic spectator" and "post-humanitarian imagination" identify with celebrities as CHOULIARAKI (2014, pp. 24, 26) pointed out.

The post-humanitarian imagination and the adjoined "economy of attention" (CітTON 2014) are characterized by several tensions: the tension between suffering and its branding; the tension between actor and victim(ization); the tension between consumer and the political (CHOUliaraKi 2014, pp. 82-83); and the tension between pathos, distance, and prudence. The demand to render the invisible visible belongs to these tensions, and thus, the quest for visibility of the marginalized may reiterate stereotypes and even promote further marginalization (SCHAFFER 2008). In such a vein, Susan SonTAg has argued that the (postcolonial) gaze on the suffering of others in art and contemporary photography adds a double message to the "unforgettable" and "ubiquitous images" of "large-eyed victims": on one hand, they expose appalling misery; on the other hand, they ontologize suffering and withdraw historical circumstances from change (SONTAG 2003, p. 56). 
The visibility of suffering not only generates victims, it also allows one to imagine the Other as threat and enemy; thus, strategies of visibilization might solidify what they seek to combat. Additionally, we should not forget that imagination is connected to massive economic interest; and that images are created to legitimize and justify the current border regime, the migration industry, and current forms of governance that depict mobile people as victim or foe.

Current policies of expanding European borders to its former colonies via bilateral or multilateral accords - such as the recent Italian accords with Libya, and European efforts to cooperate with African dictators - are intended to close the central Mediterranean route, to keep mobile people 'in their place,' and at the same time to render them invisible. Images of death are no longer produced close to European shores; death is no longer visible for the European public: it occurs out of sight in the desert.

\section{Framing Mobile People}

\subsection{Enemy}

"The overcrowded boat is a common visual representation of threatening immigration to the West. In the European context, it is usually a flimsy-looking craft filled with black Africans," GILligan and MARLEY remark (2010). Such images confirm a racialized, biopolitical security-dispositif, they call for the repulsion of 'invaders,' the 'catastrophic flood' and the 'parasites' attacking the imagined body of the nation and its prosperity. Such images legitimize the permanent state of exception (AGAmBEN 2003).

Indeed, the Italian Civil Defense Department (Protezione Civile), generally charged with coping with natural disasters, has been present on Lampedusa for decades, becoming an integral part of the tragic border regime and its economic interests. In an effort to allow this body to circumvent common rules for public tender and to promote clientelist networks, in July 2008 the government of Silvio Berlusconi declared a state of "emergency migrants." In an effort to allow this body to circumvent common rules for public tenders and to promote clientelist networks, in July 2008 the government of Silvio Berlusconi declared a state of "emergency migrants."

In February 2011 a "state of humanitarian emergency in the territory of North Africa" (sic) was again asserted "in order to allow efficient measures hindering the exceptional influx of aliens on national territory" (Presidenza DEL Consiglio DEI Ministri 2011). Part of this "emergency" was a fiscal moratorium for local tourist operators who complained about the decline of their sector, which they attributed to the recent migratory fluctuations and extensive media coverage that damaged the island's image as an 'uncontaminated' paradise. Indeed, the dominant media-gaze fostered the social imaginaire of assault. The production of such images was part of a political strategy by 
former Minister of the Interior, Roberto Maroni (Lega Nord), designed to press EU for financial aid. The arriving Tunisian harraga (migrants) were not immediately transported to mainland Sicily, but were forced to camp in the streets of the small Lampedusan village. For weeks, the island resembled an open-air television studio hosting journalists, photographers, artists, and anthropologists from all over the world who coproduced the media's 'humanitarian crisis.' The moratorium imposed by Berlusconi (who visited the island during his own politically produced 'state of emergency' to promise inhabitants milk and honey) has been extended by successive governments until 2017. This nowfamous 'state of emergency' has indeed become the island's 'new normal,' fostering the economic interests of local and national actors. ${ }^{9}$

The notion of catastrophe - from the Greek kata 'down' (cata-) + strephein turn'; katastrephein, 'to overturn, turn down' denotes the 'reversal of what is expected' (especially a fatal turning point in a drama) - has been extended to 'sudden disaster' and is part of the (tragic) border regime, the political imagination, and the permanent state of exception. ${ }^{10}$ The permanent state of emergency and the normalization of the $9 \quad$ The newly elected major of Lampedusa, a hotel owner who defeated the famous Giusi Nicolini for that role, is pressing for yet another prolongment. For an account of the (local) migration industry and clientelistic networks, see FrIESE 2012. In late 2014, Italy was shaken by the scandal Mafia Capitale. Through a network of links with politicians and businessmen, a criminal gang held an influence over public tender for cooperatives that offer services for migrants and Roma. The web of corrupt links between city hall officials, neo-fascist militants, and mobsters included Salvatore Buzzi, who was jailed for murder in 1984 . He had been alleged by prosecutors to have been the 'entrepreneurial right hand' of Massimo Carminati, the top mobster and a former member of the NAR neo-fascist terrorist group. "His organisation is claimed to have bribed officials to win contracts, including for the management of migrant-holding facilities and Roma camps. Evidence submitted by police in support of their application for warrants includes a wiretapped phone conversation in which one speaker is claimed to be 59-year-old Buzzi. 'Do you know how much you earn from immigrants?' the speaker asks. 'Drug trafficking earns less.' More than 100 other people have been formally placed under investigation, including Gianni Alemanno, the mayor of Rome from 2008 to 2013, and a former member of the neo-fascist Italian Social Movement (MSI)" (HoOper and SCAMmell 2014). Connected to investigations regarding Mafia Capitale, the links between politicians and migration entrepreneurs in Sicily came under critical scrutiny. The largest camp for asylum seekers in Europe is the CARA in Mineo/Sicily, which has been converted from a decommissioned US military base in Sigonella. The mayor of Mineo, Anna Aloisio, member of the $N c d$ (Nuovo Centro Destra/New Center-Right) party of Minister of the Interior Angelino Alfano (from the Sicilian province of Agrigento) is head of the Consorzio calatino terra di accoglienza. A member of the consortium, the coop La Cascina won a public tender worth $€ 100$ million and has been accused by investigators of Mafia Capitale because he had bribed the member of the commission with $€ 10,000$ per month. Additionally, the undersecretary Giuseppe Castiglione $(N c d)$, Angelino Alfano's right-hand man, had nominated Luca Odevaine, a man of the mentioned Salvatore Buzzi as consultant of the CARA and as member of the National Roundtable on Immigration. Odevaine confessed that he was 'compensated' by La Cascina: "They gave me $€ 10,000$ per month as... let's say, "contribution." (La Repubblica, 03.12.2014, <http://palermo.repubblica.it/cronaca/2015/03/12/news/cara_di_min... illegittima_ otto_indagati_tra_cui_un_sottosegretario-109315938/> [accessed: 15 March 2015]) In July 2017, Massimo Carminati was convicted to 20 years, and Salvatore Buzzi to 19 years of imprisonment. The court did not charge the defendants with belonging to a Mafia organization.

${ }_{10}$ 'First recorded 1748,' see <http://www.etymonline.com/index.php?term=catastrophe>. 
exception are promoted by highly symbolic visualizations of undocumented mobility. The imaginaire of mobile people as a sudden, abrupt catastrophe penetrating civil society generates a public-siege mentality against 'invasion,' which in turn has to be calmed by efficient, well-calculated measures of border management. Dominant mass-media images, policies of border management, and the state of exception are interrelated: images reiterate the exception, as the exception needs its images in order to command public and political legitimacy. At the same time, the imaginaire of catastrophy fosters (local) economic interests and the migration industry. However, not only the security industry refers to catastrophe. The scenario of catastrophe and tragedy is employed by humanitarian entrepreneurship and the need to promote and sell humanitarian aid and services on a competing market. ${ }^{11}$ Private SAR missions - as they have been carried out until recently - such as Moas, Jugend Rettet, Save the Children, SOS Mediterranée, Proactiva Open Arms, and Sea Eye - must promote their activities with drastic images of capsizing boats, drowning people, and dead black bodies.

The border regime also fosters an expanding branch of competing IGOs and NGOs (such as International Catholic Migration Committee, the International Organization for Migration, Save the Children, and Doctors Without Borders), public-private enterprises, knowledge-generating research institutes, and various other infrastructures that manage mobilities and make up a dense transnational fabric of actors, practices, policies, and powerful images of human mobility. Images of flow, invasion, crisis, and emergency are an integral part of such entrepreneurship as the media gaze produces and disseminates dominant views of undocumented mobility. This dense fabric of organizations, the security and military industry, and the European border agency (Frontex) make up the highly dynamic postcolonial border regime that connects policing, surveillance, the state of exception, and the imagination of threat that must be kept under control. Sarcastically, the militarization of borders is justified with the humanitarian fight against 'human trafficking.'

The oft-repeated image of invasion inverts the postcolonial situation: it relies on forgetting, withholding, and the repression of European colonialism, and installing instead historical revisionism. These images invoke the invasion of black masses, which take what has been taken from them; they show the phantasms of colonialism and the ghastly return of the colonized on the shores of the colonizer: the threat of a revenant.

Georg Simmel has already noted that the wanderer provokes "latent or open antagonism (Gegnerschaft)," and becomes an "irreconcilable enemy" and a "parasite of the sedentary elements of society" (SIMMEL 1992, p. 760). The provocation, the affront, is the other who menaces pollution, an intruded heterogeneity that contaminates and infects the sane body of the people, the interior of the nation, and its welfare. The intruder, the parasite, is to be detected at the borders; he is to be neutralized, and

\footnotetext{
11 For an account of the 'humanitarian industry,' see MESNARD who delineates a "doubled typology: the first one corresponds to the specific visibility of victims and the second regards both the visibility of the NGO and their own victims and the relations to rival organisations" (MESNARD 2004, p. 17).
} 
eliminated symbolically or physically by 'letting him die' (Foucault 2001, p. 291), thereby employing modern biopolitics: which is not to govern a territory but the 'own' population. As Francesca FALK notes: "[T]erritorial borders are superimposed on the boundaries of the body; migration appears at the same time as an assault upon the integrity of one's own body and that of Europe," and a "discursive and iconic connection between infection and immigration" is established (FALK 2010, pp. 89 f.).

Dominant media representations evoke catastrophe and contamination. They also repeat juridical classifications and distinguish between different categories of mobile people. At one pole exists the miserable refugee who escapes from war and annihilation; at the other pole there is the economic migrant who flees economic circumstances on the grounds of autonomous decision and will. It seems that the demonstration of individual decision and autonomy cannot be pardoned, it is exactly that demonstration that distinguishes the figure of the victim - who is not responsible for his decisions - from the enemy, the figure of threatening autonomy, decision, and will. The migrant is not only a parasite of the nation's body and welfare but an autonomous agent. Paradoxically, autonomy and will both characterize the modern subject. A helpless, needy and dependent person can be pardoned for that which in reverse marks the Other as a threat: namely autonomy, choice, and decision.

\subsection{Victim}

"The victim is [...] the hero of our times," Daniele Gigliolo boldly states (2016, p. 9). The refugee as victim is depicted as the innocent object of appalling circumstances, a victim of warfare and violence who seeks only a safer life, and who is ready to take risks, even deadly risks, in order to do so. In this, the terrifying, threatening stranger is transformed into a ward and a supplicant, a passive, needy object of temporary care who in turn must be grateful for the offering of shelter and asylum. Using the "topic of emotion, sentiment and aesthetic" (BolTANSKI 1993, p. 10), the social imagination recognizes the victim in the figure of the miserable, and turns the needy into an icon (FALK 2010, p. 86).

Usually, the dominant image of suffering and the wide-open eyes of victims capture the post-humanitarian spectator, as Susan SonTAG confirms in her remarks on the dominant "shots" and the "full frontal views" of suffering people in distant countries described in Regarding the Pain of Others (2003, p. 56). The spectator can hardly evade the direct gaze of suffering that calls for pity, and for donations. In fact, all NGOs employ these images to that end.

The post-humanitarian imagination is apolitical and ahistorical. Replacing one image of disaster with another, images are distributed around the globe with unprecedented speed, suggesting a fictitious copresence. In its need to attract funding, emotion, and authenticity, post-humanitarian discourse does not name responsibilities; it does not ask for causes or consequences; it does not have a referent other than the conveying of 
authenticity: in short, it is self-referential. Violence, ferocity, war, destruction, mobility, blind and merciless nature, pitiless fatality, and catastrophe are indiscriminately and uncritically comingled in an effort to attract attention and an immediate subjective response.

Another salient attraction of images of victims is that their closeness to physical pain creates a semblance of authenticity resulting from the unreflecting crudeness of the representation. [...] The representation of pain in images of victims does not tell a personal story, it rather generates attention by means of its event character. It suggests evidences that are not meant to inform, but to create the impression that similar events have taken place since times immemorial. By means of their irrational perspective and the persistent repetition of their motifs, they achieve a narcotic effect. From this perspective, they could be compared to spiritual imagery and its language of ritual. Mostly, representations of suffering - as a kind of visual humanism - are deployed as a means to propagate proper ethical values. In scenarios generated by PR agencies, they become mere clichés of an aesthetics of pity geared to sell issues. The overstimulation of this emotional approach to ethics numbs the viewer until he becomes used to shocks. (SonTAg 2003, p. 56)

By exposing human plight, such a discourse resembles mythical-religious narratives, erasing and overwriting time, history, and post-colonial entanglements.

Within the accelerated economy of attention, the commodification of pietà, misericordia, solidarity, and the selling of humanitarian issues via personal story-telling intends to render deplorable fate even more catchy for the consumer's subjectivity. Images of humanitarian rescue and protection against blind fate and sudden catastrophe are the only possible offer on the highly competitive market.

Identification with the victim in its visibility allows for subjectivity and ultimately, as Renata Salecl states, for the deviation of anxiety:

There seems to be an attempt in today's society to find a cure for anxiety by constantly exposing the disturbing objects that might incite it (even in contemporary arts, for example, we try to figure out what is anxietyprovoking in death by exposing cadavers). (SALECL 2004, p. 15)

This post-humanitarian discourse can be labeled as tragic because the actor must bear responsibility for his acts despite being entangled in fatal circumstances. From their own comfortable and secure shores, spectators bear witness to shipwreck, death, and destruction; in so doing, they become part of the commenting media chorus and the border regime that in one tragic breath assembles threats, victims, and heroes. 


\subsection{Hero}

The symbolism of critical discourse demanding indignation and protest is by no means autonomous; instead, it is well integrated into the current 'economy of attention.' It has to produce spectacular and tragic images in order to incite emotion, subjectivity, identification, and solidarity. Compassion is no longer tied to universal religious and moral claims (pietá, misericordia) or to the promise of salvation; and solidarity is no longer connected to critical analysis and its grand récit of revolution, but to individual feeling and the mediatized authenticity of the Other's suffering. Thus the "ironic spectator" and the call for solidarity in the "era of post-humanism" (CHOULIARAKI 2014, pp. 24, 26) are to be kindled by dramatic, 'tragic' scenarios such as shipwreck, disaster, and death, and not by the discreet and 'invisible' day-to-day existence of sans-papiers in search of a normal life.

The image of the refugee mobilizes. Compassion, in the sense that Hannah Arendt describes it, is elevated "to the rank of the supreme political passion" and "the highest political virtue" (ARENDT 1963, p. 75) without being embedded in a universalistic framework. Next to the figure of the refugee as victim is produced the figure of the refugee as hero, a hero who is acknowledged and legitimized by his dangerous, heroic voyage. In this symbolic order, the hand of the drowning victim desperately gasping for help becomes the sheet anchor of the (red) fist and battle. Compassion is converted to solidarity with refugees and, even more so, with the 'just fight of refugees.'

Alongside the topics of emotion and aesthetic, the social imagination of the refugee as hero reworks the topic of denunciation and indignation (BOLTANSKI 1993, p. 10). This symbolic transformation elevates those who are excluded from 'legal' mobility (but who mobilize nonetheless) into modern heroes of an autonomous fight for opportunity and for the realization of autonomous will. In short, the excluded become heroes of modern subjectivity.

Such representations do not refer to the humanitarian discourse and its alleged neutrality. However, paradoxically, this discourse is apolitical even as it seeks to open a political space. It is apolitical because the figure of the hero is situated between the innocent victim of capitalism and neoliberal governance on one hand, and, on the other, the figure of threat, the enemy who menaces the existing order. Whereas at one time the attention of activists was directed to the movements of liberation in the 'Third World,' and to the hope that revolutionary élan of the periphery might pressure the capitalist center, the hero of liberation has been replaced by the fighting refugee. He is to take up the fight against power and capitalism, and yet he is assigned to an asymmetric position that allows the activist to celebrate the (missed) triumph of the revolution, ensuring for himself the position of protector or guardian angel of a just and humanitarian cause.

The "Declaration of Solidarity" of the committee "Lampedusa is Everywhere" states: "The inhumane events of Lampedusa during October of 2013 are only one example of how the 'fortress Europe' claims countless human lives every day. We are 
shocked, angry and mournful that the defence (sic) of western wealth is indiscriminately violating human rights." 12 Even if critical discourse establishes analytical connections to European policies and the border regime, it falls in with the pathos of humanitarian discourses of catastrophe and victimhood, declining a scale of possible distress by the (alleged) authenticity of suffering in one's own shock, anger and mourning. By depicting victims whose autonomous actions end in tragic fatality, and even have to end in tragic fatality for its legitimizing power to be established, the tension of the tragichumanitarian discourse is repeated. Taking up the topic of denunciation, such a discourse laments the defense of affluence on one hand. On the other hand, the compassionately suffering activists participate in western prosperity, even if they seek to exorcize such participation through the displayed authenticity of emotion.

Additionally, if power works through "dispersed, heteromorphic and local procedures" which are "adopted, enforced and transformed by strategies, resistance, inertia" and therefore do not lead to "massive domination" or a binary structure of domination and subordination (FouCAULT 1994, p, 425, my translation), the fighting hero is positioned within a binary structure. For some strands of activism, the fighting hero/non-citizen is to act on behalf of those whose revolutionary practices did not succeed. Therefore, such representations must equip mobile people with revolutionary courage. In such a vein, Antonello Mangano describes the revolt of illegalized daylaborers in the Calabrian town of Rosarno in 2010 as follows: "[P]art of the Senegalese community cordoned off the villa of a capomafia [...] no one ever dared to do such a thing. This is why Africans will save us" (Mangano 2010, p. 135). Against the superior might of circumstances, the foreigner/victim/sacrificed is transformed into a redeemer, a Salvatore of the enslaved and oppressed: he is the one who acts for others and speaks on behalf of those without voices of their own. The hero redeems from voicelessness and acquits from responsibility; the image of the hero who ceaselessly fights injustice, power, and the state not only allows the spectator to celebrate victory, but allows even the hero to celebrate himself as an incessant and victorious fighter for the just cause. However, the foreigner as imagined hero, as figure of salvation, and as icon of struggle is advised to arrange that which political circumstances deny. The cult of heroes blocks claims to a life according to wishes and dreams. Mobile people cannot be inscribed into an imagined, imaginary collective subject.

The stranger, as Georg Simmel has remarked, is one who is "not tied down in his action by habit, piety, and precedent," but is "bound by no commitments which could prejudice his perception, understanding, and evaluation of the given," allowing thus for 'objectivity' and freedom (Simmel 1992, pp. 766-767, translation mine). As Bonnie Honig demonstrates, the figure of the stranger as hero and/or liberator reflects that of the "foreign founder" who inaugurates a political community, a figure well known in political thought. Rousseau's contract theory, for example, assures "a foreign founder's foreignness $[\ldots]$ the distance and impartiality needed to animate and guarantee a general

\footnotetext{
12 "Refugee Struggle for Freedom" $<$ http://refugeestruggle.org/en/solidarity/lampedusaeverywhere> [accessed: 24 October 2015], emphasis mine.
} 
Will that can neither animate nor guarantee itself" (Honig 2001, p. 21). The figure of the stranger, the foreigner as founder and lawmaker, or as immigrant, reveals the problematic nature of democracy and the its aforementioned paradox. Additionally, as a homogenous people or nation is nothing but a fiction, the foreigner always already constitutes a (political) community.

Mobility challenges democracy; it incessantly points towards the paradox of democracy and to its inclusive-exclusive structure. In fact, current national-populist "excitable speech" (BUTLER 1997) and its emphasis on borders and national sovereignty the sovereignty of an imagined homogeneous, identitarian demos to decide who belongs and who is excluded from the community - exhibits the paradox. The call for open borders or humanitarian impetuses also cannot escape this tension. Mobility challenges efforts to contain the excluded. The signifying processes of the social imagination that produce the racialized figures of mobile people as a threat, as victims, or as heroes reiterate and elaborate these tensions as well. Mobile people are none of these.

\section{References}

Agamben G. (2003), Stato di eccezione. Homo sacer II, 1. Torino, Bollati Boringhieri. (engl. State of Exception. Chicago, The University of Chicago Press, 2005).

Arendt H. (1963), On Revolution. London, Penguin, 1963.

Boltanski L. (1993), La souffrance à distance: Morale humanitaire, médias et politique. Paris: Métailié. (engl. Distant Suffering: Morality, Media and Politics. Cambridge, Cambridge University Press, 1999).

Butler J. (1997), Excitable Speech: A Politics of the Performative. New York: Routledge.

CAstoriadis C. (1987), The Imaginary Institution of Society. Cambridge, MA/Mass., Polity.

CAstoriadis C. (1997), The Greek Polis and the Creation of Democracy: The Castoriadis Reader. Oxford, Blackwell.

Cholliaraki L. (2014), Lo spettatore ironico: La solidarietà nell'epoca del post-umanitarismo (a cura die Pierluigi Musarò). Udine, Mimesis.

Citton Y. (ed.) (2014), L'économie de l'attention: Nouvel horizon du capitalisme? Paris, La Découverte.

Derrida J. (2002), Politik der Freundschaft. Frankfurt a.M., Suhrkamp.

Elliotт A. (2012), "New Individualist Configurations and the Social Imaginary: Castoriadis and Kristeva." In: European Journal of Social Theory 15.3, pp. 349-365. <DOI: $10.1177 / 1368431012440868>$

FALK F. (2010), “Invasion, Infection, Invisibility: An Iconology of Illegalized Immigration.” In: Bischoff C., FAlK F. and Kafehsy S. (eds.), Images of Illegalized Immigration: Towards a Critical Iconology of Politics. Bielefeld, transcript, pp. 83-100.

Foucault M. (1994), "Pouvoirs et stratégies." In: Defert D. and Ewald F. (eds.), Dits et écrits, Vol. II, 1970-1975. Paris, Gallimard, (1977). pp. 418-428. 
Foucault M. (2001), In Verteidigung der Gesellschaft. Vorlesungen am Collège de France (1975-76). Frankfurt a.M., Suhrkamp.

Foucault M. (2006), Sicherheit, Territorium, Bevölkerung. Geschichte der Gouvernementalität I: Vorlesungen am Collège de France 1977-1978. Frankfurt a.M., Suhrkamp.

FrIESE H. (2012), „Border Economies: Lampedusa and the Nascent Migration Industry.” In: Shima: The International Journal of Research Into Island Cultures 6.2 (Mountz A. and BrinKMAN L. (eds.) Special issue on Detention Island), pp. 66-84.

FRIESE H. (2013), “'Ya l'babour, ya mon amour' - Raï, Rap and the Desire to Escape.” In: Waligorska M. (ed.), Music, Longing and Belonging: Articulations of the Self and the Other in the Musical Realm. Newcastle, Cambridge Scholars Publishing, p. 176-201.

Friese H. (2014), Grenzen der Gastfreundschaft. Die Bootsflüchtlinge von Lampedusa und die europäische Frage. Bielefeld, transcript.

FrIESE H. (2017), Flüchtlinge: Opfer - Bedrohung - Helden. Zur politischen Imagination des Fremden. Bielefeld, transcript.

Friese H. (2017a), "Representations of Gendered Mobility and the Tragic Border Regime in the Mediterranean." In: Journal of Balkan and Near Eastern Studies 19.5, (Special Issue: Women in the Mediterranean), pp. 541-556.

Friese H. (2017b), "Repräsentationen illegalisierter Mobilität: Lampedusa als tragisches Grenzregime." In: Rass C. and Ulz M. (eds.), Migration ein Bild geben. Visuelle Aushandlungen von Diversität. Wiesbaden, Springer VS, pp. 269-296.

Gigliolo D. (2016), Die Opferfalle. Wie die Vergangenheit die Zukunft fesselt. Berlin, Matthes \& Seitz, (orig. Critica della vittima. Roma: nottetempo, 2014).

Gilligan C. and Marley C. (2010), "Migration and Divisions: Thoughts on (Anti-)Narrativity in Visual Representation of Mobile People." In: Forum Qualitative Social Research 11.2, article 32.

Honig B. (2001), Democracy and the Foreigner. Princeton, Princeton University Press.

Honneth A. (2003), Unsichtbarkeit. Stationen einer Theorie der Intersubjektivität. Frankfurt a.M., Suhrkamp.

Hooper J. and Scammell R. (2014), "Rome's 29 June Co-operative Alleged to be Base of Mafiastyle Gang." e Guardian, 7 December 2014, <http:/www.theguardian.com/world/2014/ dec/07/june-29-co-operative-italy-rome $>$ [accessed: 15 May 2015].

Mangano A. (2010), Gli africani salveranno l'Italia. Milano, BUR.

MESNARD P. (2004), Attualità della vittima: La rappresentazione umanitaria della sofferenza. Verona, ombre corte.

Musarò P. and Parmiggiani P. (eds.) (2014), Media e migrazioni: Etica, estetica e politica del discorso umanitario. Milano, Franco Angeli.

Presidenza del Consiglio dei Ministri (2011), "Dichiarazione dello stato di emergenza umanitaria nel territorio del Nord Africa per consentire un efficace contrasto all'eccezionale afflusso di cittadini extracomunitari nel territorio nazionale." Gazzetta Ufficiale n. 83 dell'11 (April 2011) <http://www.protezionecivile.gov.it/jcms/it/view_prov.wp?toptab=2\&contentIc=LE G24032\#top-content> [accessed: 21 September 2017].

SAlecl R. (2004), On Anxiety: Thinking in Action. London, Routledge.

SCHAFFER J. (2008), Ambivalenzen der Sichtbarkeit. Über die visuellen Strukturen der Anerkennung. Bielefeld, transcript. 
Simmel G. (1992), "Exkurs über den Fremden.” In: Rammstedt O. (ed.) Soziologie. Untersuchung über die Formen der Vergesellschaftung. Frankfurt a.M., Suhrkamp, 1992 [1908]. pp. 764771 (engl. The Sociology of Georg Simmel. Transl. Kurt Wolff. New York, Free Press, 1950, pp. 402-408).

Sontag S. (2003), Regarding the Pain of Others. New York, Picador. $<\mathrm{http} / /$ monoskop.org/images/a/a6/Sontag_Susan_2003_Regarding_the_Pain_of_Others. pdf> [accessed: 30 December 2014].

UNHCR (2015), Global Trends: Forced Displacement in 2015. <www.unhcr.org/576408cd7> [accessed: 02 August 2017] 